\title{
GENDER AND SOCIAL MEDIA IN PRODUCT INNOVATION SEARCHING PROCESS
}

\begin{abstract}
Social media is one of the most important and popular platforms to exchange information on new products and services. Social media is particularly important for purchasing decisions by young adults, called Millennials. The main goal of the article is to examine the role of social media in obtaining information on innovative products by Millennials. In addition, the research analyses differences in perceptions of the role social media plays in the purchasing process, including the gender of surveyed buyers. The hypotheses are based on a conceptual model utilising the theory of innovation diffusion and the theory of consumer behaviour. We used Structural Equation Modeling (SEM) as a research method. The research sample consisted of buyers representing the Millennial generation. The findings confirmed the positive impact of the selected factors on using social media to search for innovative products. The study also confirmed gender differences in perceptions of the importance of social media. The biggest differences between men and women relate to assessing the importance of information availability, convenience, and habit.
\end{abstract}

Keywords: social media, gender, process of product searching.

\section{INTRODUCTION}

The rapid development of ICT technology increases the extent and frequency of using Internet resources by people around the world. More and more new opportunities offered via the Internet also affect development and changes in the areas of market activity, both for individual buyers and enterprises (Voorveld, Smit, Neijens, Bronner, 2016). The Internet allows market participants not only to access interesting and useful information quickly, but it also enables the users to communicate freely as well as expressing their opinions about products, enterprises and brands (Rezaei, Valaei, 2017; Tkaczyk, 2015).

Along with the development of ICT, marketing interest in consumer activity in social media is also growing. The emergence of social media has caused a significant breakthrough in using the Internet because they have enabled users to actively engage and function online in a way previously unavailable (Lipowski, Bondos, 2016). Thanks to social media, people not only keep in touch with friends, but also can collect information about

\footnotetext{
${ }^{1}$ Marek Angowski, PhD, Department of Microeconomics and Applied Economics, Faculty of Economics, Maria Curie-Sklodowska University in Lublin, Pl. M. Curie-Skłodowskiej 5, 20-031 Lublin; e-mail: marek.angowski@umcs.lublin.pl. ORCID: 0000-0003-1669-5073.

2 Tomasz Kijek, DSc PhD, Prof. UMCS, Department of Microeconomics and Applied Economics, Faculty of Economics, Maria Curie-Sklodowska University in Lublin, Pl. M. Curie-Skłodowskiej 5, 20-031 Lublin; e-mail: tomasz.kijek@umcs.lublin.pl; ORCID: 0000-0002-0134-4943
} 
world events and exchange information about brands and companies. Social media has also contributed to the emergence of new methods and tools through which buyers can provide information about products and services (Kuczamer-Kłopotowska, 2016; Sands, Ferraro, Campbell, Pallant, 2016).

The range of online buyer activity is expanding at a very fast pace. Buyers using the internet can take part in many different activities related to market processes, from reading content to participating in discussions and sharing knowledge with other consumers (Pauwels, Leeflang, Teerling, Huizingh, 2011).

The process of buyer behavior on the market consists of actions aimed at satisfying a specific need (Szlegr, 2018). Consumer behavior describes as a sum of the individual's actions and perceptions, which include preparation for the decision to purchase a product, its selection and consumption. In this case, consumer behavior concerns three types of reaction: communication, purchase and consumption (Nguyen, Leeuw, Dullaert, 2018). There are many traditional models of consumer behavior in the literature. One of the basic features of the most popular behavior model is a large number and variety of factors that affect the stages of communication and purchase. One of the main determinants is information about the product that the consumer wants to buy. There are many different sources of pre-consumer information. Today, the Internet is usually the first and most dominant source (Shao, Chen, 2019; Zhang, Benyoucef, 2016).

The widespread use of ICT in marketing has resulted in the emergence of a new type of communication message in marketing called e-WoM. The e-WoM concept is developing very rapidly and today plays a key role in the consumer decision making process. The process begins with searching for product information (pre-consumption stage) and ends with the after-sales stage, which refers to post-use or consumption experiences (Al. Majzoub, Davidaviciene, 2019).

In marketing literature, the method of exchanging such information among buyers in direct communication is called Word of Mouth (WoM) (Chu,Kim, 2011).

A particularly important event in the development of e-WoM was the emergence of social media, which due to their specificity, allow users to communicate and transfer content even faster (Sanchez Torres, Arroyo-Cañada, Solé-Moro, Argila-Irurita, 2017).

E-WoM is currently an extremely important source of obtaining information about products, services and brands in the process of making decisions about purchasing them, because they give the impression of being much more reliable than conventional forms of communication, such as advertising or recommendations from sellers and producers (Duarte, Costa e Silva, Ferreira, 2018). Buyers can, practically without restrictions, ask other consumers via social media what their opinions about specific products or sellers are (Erkan, Evans, 2016). Such behavior usually occurs before the purchase decision or after consumption. When they lack sufficient knowledge or have doubts about the features of products available on the market, buyers ask questions before buying a product. However, they share their knowledge after having purchased a product when they want to recommend proven products or warn others of low quality products or unreliable sellers (Erkan, Elwalda, Rahman, Sap, Dogan, 2017). 


\section{IMPACT OF GENDER ON THE BEHAVIOR OF BUYERS IN THE PURCHASE PROCESS}

Product selection and purchase is a very complicated and complex process which is shaped by a number of various factors. The factors that are most frequently mentioned in the literature are the economic and marketing ones (price, income, offer, brand, sales location, distribution methods, advertising and commercial promotions, etc.), the psychological ones (motives and attitudes of purchase, perception and learning, personality, habits, customs, etc.), and the socio-cultural ones (social groups, family, friends, religion, tradition, etc.). In addition, among the factors determining the behavior of buyers, demographic factors such as gender and age of consumers are very often mentioned (Angowski, Kijek, 2017). Although it is clear that the significance of social, psychological and cultural factors in explaining buyer behavior in the market is increasing, it is demographic factors, describing the human as a consumer, that are still one of the main criteria for the division of consumers used in their segmentation (Kowalska, 2019).

Due to the fact that the sex of buyers is a very important determinant of their behavior in the market, it is very often used as a criterion for market segmentation in marketing strategies of commercial enterprises. It is assumed that women and men differ significantly in their behavior, both in the process of collecting information and in the process of making choice and purchasing decisions. The differences between the sexes pertain to their different perception of market realities, product or seller preferences, market priorities and motives, needs and interests, relationships with other market participants, expectations and requirements related to communication and information processing capabilities (Kąkol, 2017; Trivedi, Teichert, 2019).

There is a difference in the way men and women prepare for shopping: they differently browse the offer and evaluate the products, they use different sets of factors that influence their final choices. Therefore, guided by the same need, but often completely different motivation, women and men make shopping decisions in a different way (Mysona-Byrska, 2016).

The difference in market behavior of men and women can already be seen in their perception of shopping as an activity. For a man, buying is just a way of purchasing a new item in order to meet a specific need. A man tries to buy goods only when it is really necessary and thus shopping is a tedious process for him. Visits to stores are tiring and stressful, and therefore a man tries to keep their length to a minimum. The behavior of men in the market is primarily focused on achieving the goal as well as on desire to be successful and the need to gain an advantage. On the other hand, men perceive the purchase process as something like a hunt or mission, and the result depending on the result can be treated as a personal success or failure (Deluga 2015).

For women, shopping is not just a way to buy a new product. The process of searching and buying can be a kind of adventure for them, a nice leisure time, a way to relax and destress. (Richard, Chebat, Yang, Petrevu, 2010).

The purchase process for men is linear. In the process of making a purchase decision, a man seeking a good solution tries to follow the simplest possible way with the intention of achieving his goal. Identification of the needs starts the process of searching for information and selecting key product features for the buyer. While searching for the desired product, he eliminates those variants that do not meet the assumed criteria and as a result tries to limit the selection to only a few most important items. Having set the precise 
requirements for the offer, he usually purchases quite quickly and decisively (Kowalska, 2019; Lipowski, Angowski, 2016).

The woman thinks in network style, constantly collecting information. She checks prices, asks friends for opinions on a given item, even if she is not going to buy it. For most of them, the time spent on shopping is not important, it is more important to find the perfect solution. Therefore, the purchasing process for women may take longer than for men. The woman will check whether the product or service has all the desired features and whether it meets all the criteria. She is not satisfied with the fact that the product or service meets some of the expected features, the demanded offer must have all the ideal features, otherwise she will not buy it but will continue to search asking sellers about further details of the product or service (Deluga 2015, Zatwarnicka-Madura, 2016).

For women, the decision-making process is formed by a tendency to have relationships with other people, focusing on team play, striving for their own perfection, perceiving other people, empathy (Kąkol, 2017; Kowalska, 2017).

Women's network thinking means that they perceive the marketing mix as a whole, at the same time noticing all its elements. In the case of men, however, due to their analytical and linear thinking, the perception of marketing mix is different. Women can focus on several of its elements at the same time. Men usually see only what they need at the moment of making a decision. For men, details do not play a significant role. It is certificates and plain, preferably numerical, data that are more important (Deluga 2015; Lipowski, Angowski, 2016).

The purchase process does not end with buying the product, as women tend to share their knowledge and stay loyal for a long time if their expectations are met. Recommendations play an important role for women. Women not only inquire willingly, but they share their comments on the shopping experience more frequently. Therefore, they have an influence on a wide range of people with whom they talk about products (Asada, Ko, 2019; Richard, Chebat, Yang, Petrevu, 2010)

Due to the fact that there are significant differences between women and men in the purchasing process, the specifics of making decisions and making market choices by them should be taken into account in the design and implementation of marketing activities of enterprises operating on a competitive market, especially in marketing communication strategies.

\section{METHODOLOGY AND RESEARCH RESULTS}

\subsection{Data and methods}

The purpose of the publication is to analyze the impact the gender of buyers has on their use of information from social media in the process of searching and selecting innovative products. The main research problems are: determining whether and how the gender of the buyer affects the way how information is used through social media when making purchasing decisions.

In the process of preparing the research part, the results of a survey on the behavior of buyers in the product selection process, that was conducted in the generation group of Milennials (the people born at the turn of the 20th and 21th centuries), were used. The research was carried out in 2018 in a group of 315 students from universities in Lublin and Siedlce. The methods used to collect the research material were PAPI (Paper and Pen Personal Interview) and CAWI (Computer-Assisted Web Interview) methods. 
Table 1 presents the distribution of age and sex of the respondents. Women constituted the bigger group in the sample of buyers. As for the age of respondents, the largest group were people under the age of 21 .

Table 1. The characterization of the surveyed respondents $\mathrm{N}=315$

\begin{tabular}{|c|c|c|c|}
\hline Item & Characteristic & $\mathrm{n}$ & $\%$ \\
\hline \multirow{3}{*}{ Age } & to 21 & 165 & 52,4 \\
\cline { 2 - 4 } & $22-25$ & 126 & 40,0 \\
\cline { 2 - 4 } & over 25 & 24 & 7,6 \\
\hline \multirow{2}{*}{ Gender } & Female & 211 & 67,0 \\
\cline { 2 - 4 } & Male & 104 & 33,0 \\
\hline
\end{tabular}

Source: own calculation.

During the study, the respondents were asked to give their opinions on statements about using social media to obtain information about product innovations, and in particular: the features of information and its usefulness in the decision-making process, the way social media are used, as well as their attractiveness and efficiency in the purchase process.

Before completing the paper version of the questionnaire (PAPI method), the interviewer explained the concept of product innovation to the respondents, while in the case of the electronic version (CAWI) the explanation of the concept was attached to the invitation to participate in the survey which was sent by email. To assess the behavior of buyers, the questionnaire was comprised of questions containing five-point Likert scales, ranging from strongly disagree -1 to strongly agree -5 .

Looking for the direct contribution of social media to new products browsing, we use a structural-equations model (SEM). Structural equation modeling is a statistical method applied in the behavioral sciences for the quantification and verifying of substantive theories and may be regarded as a combination of a broad array of models from linear regression to measurement models to simultaneous equations, including confirmatory factor analysis (CFA), correlated uniqueness models, and latent growth models. SEM enjoys a few advantages over other analysis techniques, since it can test proposed causal paths among constructs. We fit combined models across subgroups of the data. These subgroups are males and females. We have analyzed data by using STATA 16.

\subsection{Research model and hypotheses}

The dynamic development of ICT has meant that using social media tools to search for market information is becoming more and more common. Not only the widespread access to the internet is increasing, but also the ICT tools used in obtaining information are becoming more multifunctional and convenient to use. There are many different concepts in the literature on the subject of the factors that shape the use of social media in the purchasing process. Having studied the subject literature, the authors have selected the factors that shape the use of social media by Millenials who seek information needed to make decisions to buy innovative products (Figure 1).

The presented model shows the four groups of factors which affect the propensity to use social media in the process of obtaining information on innovative products: information availability, convenience, habit and adventure. 
The decision to choose information availability and convenience is related to the fact that the Internet is currently the largest source one can obtain information from. One needs just a few "clicks" to find the necessary information about the product or seller. One may say that the resources of such information are unlimited. Buyers looking for information about a product or service, not only reach information easily and quickly, but they can also search for it at any time and regardless of where they are. In addition, social media allow users to reach comprehensive information through the synergy of information from a variety of sources related to the product (Ashraf, Hou, Ahmad, 2019; Pöyry, Parvinen, Malmivaara, 2013).

Another group of factors is the impact of habit and adventure. The habits and customs associated with using social media have an influence on chosing them as a tool of searching for information on innovative products or services. This may be particularly important in the case of the Millennials generation group, for whom the Internet environment is something natural and social media is the basic tool for obtaining and exchanging information. Additionally, using social media and browsing products online can be perceived by users as excitement, pleasure, fun, adventure and the feeling of satisfaction associated with them (Kim, Eastin, 2011).

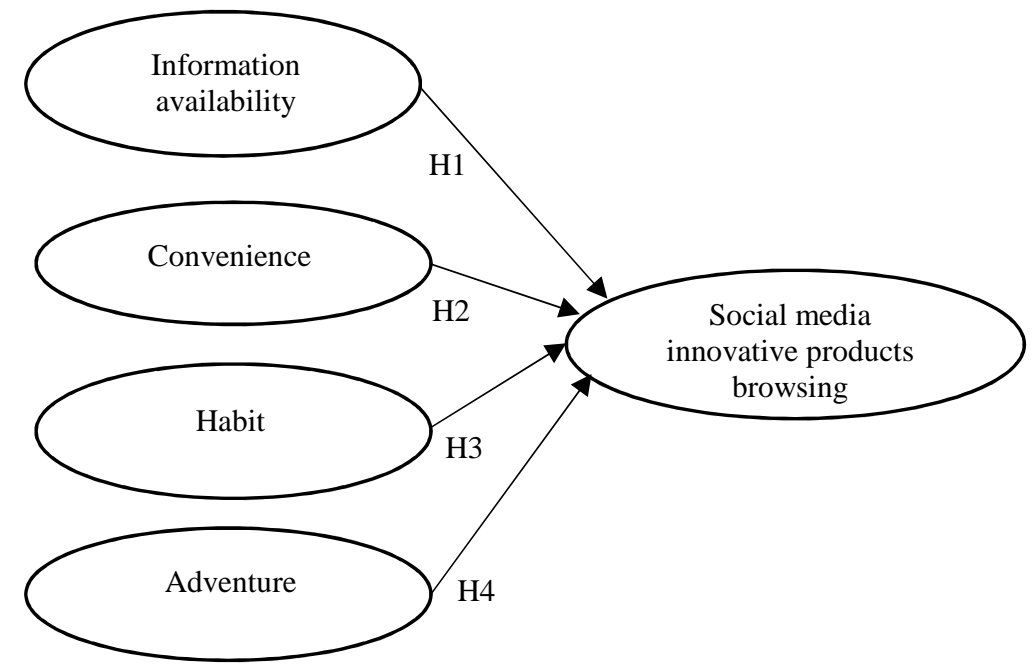

Figure 1. Research model

Source: own calculation.

Considering gender as a factor differentiating relations presented in the research model, the following research hypotheses were formulated:

- H1: the impact of information availability on the tendency to use social media when searching for innovative products is stronger in the group of women than men.

- H2: the impact of convenience factors on the propensity to use social media when looking for innovative products is stronger in the group of women than men.

- H3: the impact of habits and customs on the tendency to use social media when searching for innovative products is stronger in the group of women than men. 
- H4: the impact of adventure related factors in the purchasing process on the propensity to use social media when searching for innovative products is stronger in the group of women than men.

\subsection{Results}

For the measurement property assessment, confirmatory factor analysis (CFA) has been conducted. The results for CFA gained standardized factor loadings above 0.45 indicate that that item is considered a satisfactory/fair item.

The results of estimating the model of structural equations in two groups of respondents (i.e. women and men) are presented in Figure 2 and Figure 3. Furthermore, Figure 2 and Figure 3 also provide information on predicting power $\left(\mathrm{R}^{2}\right)$ for each dependent variable. $\mathrm{R}^{2}$ shows the percentage of total variance in the dependent variable explained by the independent variables. This implies that our models account for $64 \%$ and $48 \%$ of the total variance of social media innovative products browsing in two groups respectively. These values represent an acceptable explanatory power. As regards the coefficient of determination for whole models the values close to 1 indicate a good fit.

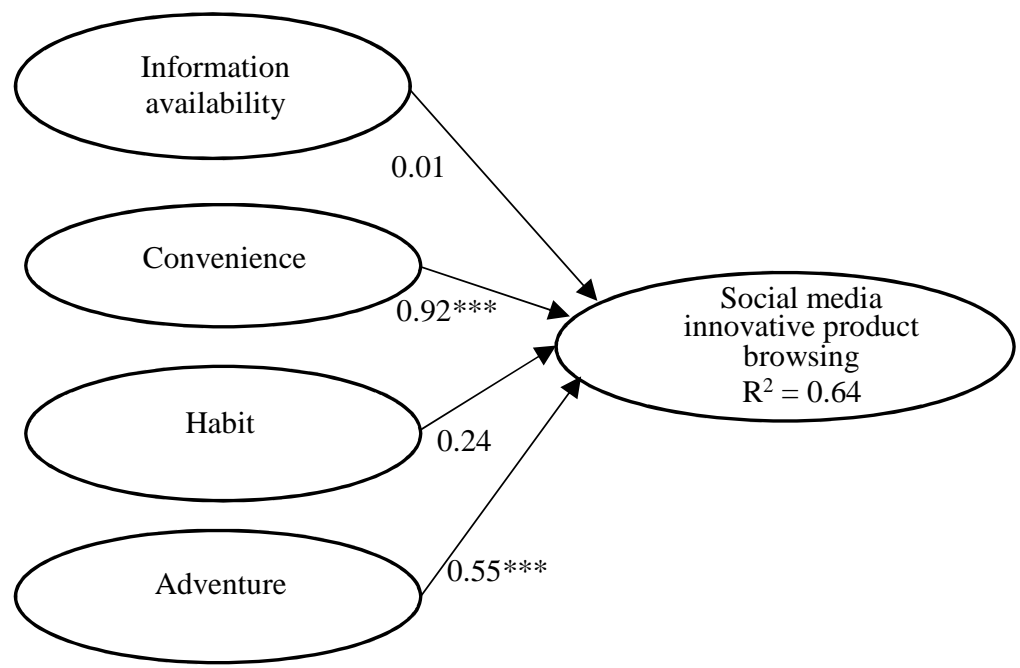

Figure 2. Model parameter estimation in the group of male

Source: own calculation

As can be seen from the figure above, in the group of men, factors related to convenient, fast and efficient achievement of the goal, i.e. finding and buying products, have the greatest impact on using social media to search for new products. Adventure is another important factor affecting men's behavior in the process of searching for a product. Men / buyers can treat the purchase task as a challenge and competition, and the purchase as a success. To a lesser extent, the choice of social media in the search for innovative products was influenced by consumer habits and the availability of information. The availability of information is of least importance to the surveyed buyers. There may be some connection 
with adventure, i.e. if the information is lacking, finding and obtaining it may become a challenge and additional satisfaction if the activity is successful.

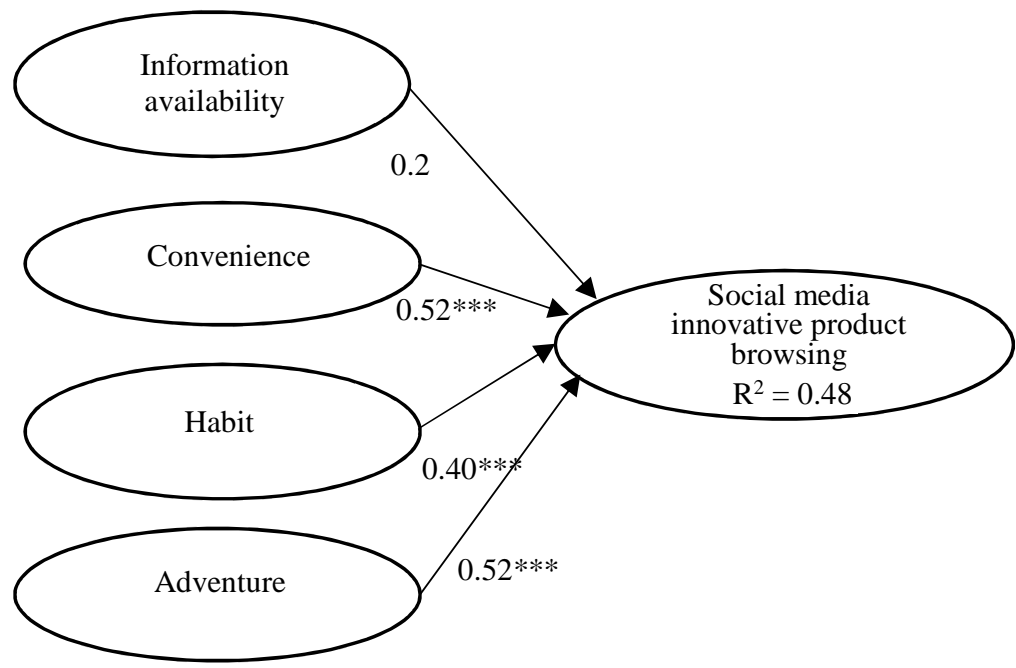

Figure 3. Model parameter estimation in the group of female

Source: own calculation

In the case of the examined group of women, convenience is also the most important factor in the process of seeking information on new products, but as one can see, to a relatively lesser extent than in the case of the male group. For women, it's not about time, but rather about the ease of using social media tools in searching and analyzing as much market information as possible. An additional advantage of using social media in the purchase process for this group of buyers is the ease of interacting and the ability to share information with other market participants. Taking the conducted research into account, one can also observe a greater than in the case of the male group significance of factors related to the availability and scope of information in the Internet needed to make a purchase decision, as well as factors related to shopping habits. As mentioned in the theoretical part, for women, shopping is "something" more than just the process of purchasing a product or service. Shopping is also a way to spend free time, a way to relax or contact with friends.

\section{CONCLUSIONS}

The development of information technologies has made the Internet one of the commonest sources of information on new products for modern buyers. Social media are one of the tools that not only enables to search for information passively, but also actively create or exchange it with other users.

The research conducted on a group of buyers representing the Millenial generation confirmed the importance of social media in the process of obtaining information on innovative products. Having analyzed the factors that affect the inclination to use social media as a method of obtaining information on innovative products, it may be concluded that it is the factors from the convenience and adventure group that had the strongest 
stimulating effect on the decisions of the surveyed buyers. The factors related to habit were affected to a lesser extent. However, the impact of factors associated with information availability turned out to be insignificant. It should be noted that the biggest differences in the perception of the role social media have in the process of obtaining information on new products occurred in the assessment of convenience and habit. Among the respondents, in the groups distinguished by the criterion of sex, the factor of convenience was more important for men whereas the factor of habit was more important for women.

The results of the research, due to the sampling methodology adopted by the authors, are not representative, but may be a starting point for further research focused on analyzing factors related to new technologies that determine the rate of diffusion of product innovations among consumers.

\section{REFERENCES}

Al Majzoub, K., Vida Davidavičienè, V. (2019). Development of ICT: Conceptual Comparative Analysis of Consumer Behavior in Europe and Asia. Contemporary Issues in Business, Management and Economics Engineering'2019, International Scientific Conference, 9-10 May 2019, Vilnius, Lithuania. DOI: 10.3846/cibmee.2019.090.

Angowski, M., Kijek, T. (2017). Segmentacja nabywców na podstawie analizy czynników wpływajacych na wybór produktów żywnościowych. „Humanities and Social Sciences”, Vol. 22, No. 24(3). DOI: 10.7862/rz.2017.hss.40.

Asada, A., Ko, J.Y. (2019) Perceived Influence of Word-of-Mouth Recommendation on SportWatching Behavior: A Gender Difference Perspective. "Sport Marketing Quarterly”, Vol. 28. DOI: 10.32731/SMQ.283.092019.02.

Ashraf, R.U., Hou, F., Ahmad, W. (2019) Understanding Continuance Intention to Use Social Media in China: The Roles of Personality Drivers, Hedonic Value, and Utilitarian Value. "International Journal of Human-Computer Interaction", Vol. 35, 13. DOI: 10.1080/ 10447318.2018.1519145

Chu SC, Kim Y. (2011) Determinants of consumer engagement in electronic word-of-mouth (eWOM) in social networking sites. "International Journal of Advertising”, Vol. 30, No. 1. DOI: 10.2501/IJA-30-1-047-075.

Deluga, W. (2015). Miejsce gender marketingu w postępowaniu nabywców na rynku dóbr szybko zbywalnych. „Problemy Profesjologii”, Vol. 1.

Duarte, P., Costa e Silva, S., Ferreira, M.B. (2018). How convenient is it? Delivering online shopping convenience to enhance customer satisfaction and encourage e-WOM. "Journal of Retailing and Consumer Services”, Vol. 44(C). DOI: 10.1016/j.jretconser.2018.06.007.

Erkan, I., Elwalda, A., Rahman, M., Sap, S., Doğan, S. (2017). Mobile word of mouth (MWOM) in messaging applications: An integrative framework of the impact of MWOM communication. "International Journal of Applied Business and Management Studies”, Vol. 2, No. 1.

Erkan, I., Evans, C. (2016). Social media or shopping websites? The influence of eWOM on consumers' online purchase intentions. "Journal of Marketing Communications". DOI: 10.1080/13527266.2016.1184706.

Kąkol, P. (2017). Communication and its differences among men and women. "Humanities and Social Sciences”, Vol. 22, 24 (3/2017). DOI: 10.7862/rz.2017.hss.48.

Kim, S., Eastin, M.S. (2011). Hedonic Tendencies and the Online Consumer: An Investigation of the Online Shopping Process. "Journal of Internet Commerce", Vol. 10. DOI: 10.1080/ 15332861.2011.558458. 
Kowalska, M. (2019). Rola ptci $w$ budowaniu relacji na poziomie afektywnym $w$ środowisku online na przykładzie generacji Y. „Przedsiębiorczość i Zarządzanie”, Vol. 20, 6.

Kuczamer-Kłopotowska, S. (2016) Rola mediów spotecznościowych w komunikacji pokolenia Y. „Handel Wewnętrzny”, 3, 362.

Lipowski, M., Angowski, M. (2016). Gender and consumer behaviour in distribution channels of services. "International Journal of Synergy and Research", Vol. 5. DOI: 10.17951/ ijsr.2016.5.45.

Lipowski, M., Bondos, I. (2016). Omnikanałowość-czy rynek zweryfikuje koncepcję teoretyczna. „Organizacja i Zarzadzanie”, No. 1.

Mysona Byrska, J. (2016). The female consumer,w she is, who she wants to be and who she cannot be as a consumer. "Humanities and Social Sciences", Vol. 21, 23 (4/2016). DOI: 10.7862/rz.2016.hss.70.

Nguyen, D.H., Leeuw, S., Dullaert, W.E.H. (2018). Consumer behaviour and order fulfilment in online retailing - A systematic review. "International Journal of Management Reviews", Vol. 20. DOI: $10.1111 /$ ijmr.12129.

Pauwels, K., Leeflang, P.S.H., Teerling, M.L., Huizingh, K.R.E. (2011). Does Online Information Drive Offline Revenues? Only for specific Products and Consumer Segments! “Journal of Retailing”, 87, 1. DOI: 10,1016/j.jretai.2010.10.001.

Pöyry, E., Parvinen, P., Malmivaara, T. (2013). Can we get from liking to buying? Behavioral differences in hedonic and utilitarian Facebook usage. "Electronic Commerce Research and Applications”, Vol. 12. DOI: 10.1016/j.elerap.2013.01.003.

Rezaei, S., Valaei, N. (2017). Branding in a multichannel retail environment. "Information Technology \& People”, Vol. 30, No. 4. DOI: 10.1108/ITP-12-2015-0308.

Richard, M-O. Chebat, J-C., Yang, Z., Putrevu, S. (2010). A proposed model of online consumer behavior: Assessing the role of gender. "Journal of Business Research", Vol. 63. DOI: 10.1016/j.jbusres.2009.02.027.

Sánchez Torres, J.A., Arroyo-Cañada, F.J., Solé-Moro, M.L., Argila-Irurita, A. (2017). Impact of gender on the acceptance of electronic word-of-mouth (eWOM) information in Spain. “Contaduría y Administración”, Vol. 63, No. 4. DOI: 10.22201/fca.24488410e.2018.1428.

Sands, S., Ferraro, C., Campbell, C., Pallant, J. (2016). Segmenting multichannel consumers across search, purchase and after-sales. "Journal of Retailing and Consumer Services", No. 33. DOI: 10.1016/j.jretconser.2016.08.001.

Shao, P., Chen, H. (2019). Driving Factors for Opinion Diffusion Behavior in Consumers on Online Social Networks: A Study of Network Characteristics. IEEE Access, Vol. 7. DOI: 10.1109/ACCESS.2019.2932571.

Szlegr, M. (2018). Analiza zachowań konsumentów podczas zakupów on-line. "MIND Journal", No. 5.

Tkaczyk, J. (2015) Źródła informacji $w$ procesie podejmowania decyzji o zakupie przez e-konsumentów - Polska na tle innych państw UE. „Marketing i Rynek”, No. 8.

Trivedi, R.H., Teichert, T. (2019). The effect of ad smiles on consumer attitudes and intentions: Influence of model gender and consumer gender. "Journal of Business Research", Vol. 99. DOI: 10.1016/j.jbusres.2019.02.052.

Voorveld, H.A.M., Smit, E.G. Neijens, P.C., Bronner, A.E.F. (2016). Consumers' CrossChannel Use in Online and Offline Purchases. An Analysis of Cross-Media And Cross-Channel Behaviors between Products. "Journal of Advertising Research", 12. DOI: 10.2501/JAR-2016044 D. 
Zatwarnicka-Madura, B. (2016). Online marketing communication directed to women in the car market. "Humanities and Social Sciences", Vol. 21, 23(3/2016). DOI: 10.7862/rz.2016.hss.56.

Zhang, K.Z. and Benyoucef, M. (2016). Consumer behavior in social commerce: a literature review. "Decision Support Systems", Vol. 86, No. 1. DOI: 10.1016.j.dss.2016.04.001.

DOI: $10.7862 /$ rz.2019.hss.32

The text was submitted to the editorial office: November 2019.

The text was accepted for publication: December 2019. 
